\section{B A Institute of \\ YK Business Administration \\ 六下 \\ Karachi \\ Leadership and Ideas for Tomorrow}

Business Review

Volume 2 Issue 1 January - June 2007

$1-1-2007$

\title{
The scale of operation, profitability based productivity and capacity utilization in seaports, the case study based on the Colombo Seaport in Sri Lanka, 1980-2005
}

Sarath W.S.B Dasanayaka

Institute of Business Administration, Karachi, Pakistan

Follow this and additional works at: https://ir.iba.edu.pk/businessreview

Part of the Operations and Supply Chain Management Commons

(c) (i)

This work is licensed under a Creative Commons Attribution 4.0 International License.

\section{Recommended Citation}

Dasanayaka, S. W. (2007). The scale of operation, profitability based productivity and capacity utilization in seaports, the case study based on the Colombo Seaport in Sri Lanka, 1980-2005. Business Review, 2(1), 99-116. Retrieved from https://doi.org/10.54784/1990-6587.1115

This article is brought to you by iRepository for open access under the Creative Commons Attribution 4.0 License and is available at https://ir.iba.edu.pk/businessreview/vol2/iss1/8. For more information, please contact irepository@iba.edu.pk. 


\title{
ARTICLE \\ The Scale of Operation, Profitability based Productivity and Capacity Utilization in Seaports, The Case Study based on the Colombo Seaport in Sri Lanka, 1980-2005
}

Sarath W.S.B. Dasanayaka

Institute of Business Administration, Karachi, Pakistan

\begin{abstract}
The Sri Lanka (formerly Ceylon), an island nation, is strategically located in the South Asian main sea routes as a gateway to the Far-East, the Middle-East, Europe, Africa and Australia. This supreme strategic hub location created commendable achievements in seaports in different magnitudes over time. More specifically, after 1977 economic policy reforms, the Colombo seaport has earned the reputation as the best managed and the most efficient hub port in the South Asia and the major transshipment center in the Indian Ocean. This success further strengthened by the liberalization of shipping in 1990 which was the land mark of changing the fundamentals of the Sri Lankan shipping and ports related activities. In terms of future prospects of transshipment activities in South Asia, it can be estimated that, with the size of vessels growing in the main routes and economic booms in India and China, there will be a concentration of transshipment activities on a very limited number of strategically located hub ports equipped to cope with future generation of vessels requirements and ensuring excellent operation conditions. Therefore it is obvious that the Colombo's qualifications are deemed fit to become one of these major hub in the South Asia. In this context, the recent growth of the Colombo seaport is analyzed by using production function, profitability and capacity utilization approach to get more insights into the seaport operation and to find the possibilities for further expansion. This new approach may overcome the potential problems of port impact and cost benefits studies. First this study conclude that the analysis based on the Cobb-Douglas production function has shown that the operation of the Colombo seaport is an increasing return to scale during the recent past. The returns to scale depends to a larger extent upon changing demand for seaport services and corresponding development to cope with this demand. In view of the rapidly rising tonnage handled and the other services provided for ships and the related other business activities by the Colombo seaport after the 1977 policy reforms has reasonable evidences to find increasing returns to scale in our estimated models even with some what ambiguous data set. Second the profitability based productivity analysis shows the average profitability measures such as the marginal revenue product of labour (MRPI) is very high compared to the average wage rate paid for labour $(W)$ and the marginal revenue product of capital $(M R P k)$ is very high compared to the interest rate $(r \%)$ paid for the port development loans. Furthermore, the small fluctuation of the Lagrange multipliers in the estimated max-min model
\end{abstract}


indicates the sustainable nature of profitability of operations in the Colombo seaport. Finally the capacity utilization analysis shows that annual rate of increase of tonnage at the Colombo seaport has been positive and, the rate has increased at an increasing rate over time and it shows the high rate of actual to preferred capacity utilization which can be used as a basis to expand seaport facilities without creating the problem of overcapacity. This new approach can be use to any seaports in any parts of the world to see their scale of operation, profitability based on the productivity and capacity utilization aspects before major expansion in capacity.

\section{INTRODUCTION}

ri Lanka, by virtue of its mid-way position in the Indian Ocean, has been throughout $\checkmark$ her history a famous meeting place of foreign merchants and travelers. Arab coasters, Greek and Roman galleys as well as Persian merchants visited the ancient harbours of the Sri Lanka to rendezvous with vessels form the East for trading purposes. Therefore, economic and cultural inter-changes, trade links, colonization, roots of industrialization, urban and commercial centers and most of the imports and exports based modern business activities have emerged through the seaports. At present, Sri Lanka has four major international seaports (Colombo, Galle, Trincomalee and Kankasanturai) however, Colombo (commercial capital city of the island) is the most developed one which handles over $90 \%$ of the country's sea-borne trade. After the 1977 economic policy reforms ${ }^{1}$, the Colombo seaport has earned the reputation as the best managed and the most efficient hub port in the South Asia and the major transshipment centre in the Indian Ocean. This success further strengthened by the liberalization of shipping in $1990^{2}$ which was the land mark of changing the fundamentals of the Sri Lankan maritime activities. In terms of future prospects of transshipment activities in South Asia, it can be estimated that, with the size of vessels growing in the main routes, there will be a concentration of transshipment activities on a very limited number of strategically located hub ports equipped to cope with future generation of vessels requirements and ensuring excellent working conditions. UNCTAD (1990) has more frankly emphasized that Colombo's qualifications are deemed fit to become one of these major hub in the South Asia. In this context, the recent growth of the Colombo seaport is analyzed by using production function, profitability and capacity utilization approaches to get more insights into the seaport operation and to find the possibilities for further expansion. This new approach may overcome the potential problems of expensive port impact and cost benefits studies ${ }^{3}$. First, this paper presents the scale of operation in three major seaports (Colombo, Galle and Trincomalee) and later more exclusively the situation of the Colombo seaport. Second, it presents the productivity based profitability analysis in the Colombo seaport. Third, the actual to preferred capacity utilization analysis in the Colombo seaport is presented. Finally, conclusions, notes and references are followed.

\section{SCALE OF OPERATION ANALYSIS}

The following conventional Cobb-Douglas production function is the main analytical tool of this section, which generally captures the basic ingredients of seaport operations and it is estimated by using E-views statistical package. 
$Q=A K^{a} L^{b} e^{t(T / L)}$

Where

$\mathrm{Q}=$ output (gross port revenue, 1980 prices), $\mathrm{K}$ = capital inputs (capital employed book value, 1980 prices), $\mathrm{L}=$ labor inputs (wages and salaries paid, 1980 prices), $\mathrm{a}$ and $\mathrm{b}=$ capital and labor ratios, $\mathrm{e}(\mathrm{T} / \mathrm{L})=$ proxy for technological improvement: $\mathrm{T}=$ total tonnage handled, $\mathrm{L}=$ number of employees, $(\mathrm{T} / \mathrm{L})=$ tonnage per unit of labor.

This non-linear relationship can be linearize by using log transformation as follows:

Using properties of the logarithms

$$
\begin{aligned}
& \ln (\mathrm{AB})=\ln \mathrm{A}+\ln \mathrm{B} \\
& \ln \left(\mathrm{A}^{\mathrm{k}}\right)=\mathrm{k} \ln \mathrm{A} \\
& \ln \mathrm{Q}=\ln \mathrm{A}+\mathrm{a} \ln \mathrm{k}+\mathrm{b} \ln \mathrm{L}+(\mathrm{T} / \mathrm{L}) \ln \mathrm{e}^{\mathrm{Z}}+\mathrm{U} \\
& \quad \mathrm{B} e i n g \ln \mathrm{e}=\log _{\mathrm{e}} \mathrm{e}=1 \\
& \ln \mathrm{Q}=\ln \mathrm{A}+\ln \mathrm{A}+\mathrm{a} \ln \mathrm{k}+\mathrm{b} \ln \mathrm{L}+\mathrm{Z}(\mathrm{T} / \mathrm{L})+\mathrm{U} \\
& \quad \text { where } \mathrm{A}^{*}=\ln \mathrm{A} \\
& \ln Q=A^{*}+a \ln K+b \ln L+Z(T / L)+U \ldots(1) \text { Model with technology proxy }
\end{aligned}
$$

$\ln Q=A^{*}+a \ln K+b \ln L+U$

(2) Model without technology proxy

\section{Estimation of the Production Function for Major Sri Lankan Seaports}

$$
\ln \mathrm{Q}=\mathrm{A}^{*}+\mathrm{a} \ln \mathrm{K}+\mathrm{b} \ln \mathrm{L}+\mathrm{Z}(\mathrm{T} / \mathrm{L})+\mathrm{U}
$$

Let,

$$
\begin{aligned}
& \ln \mathrm{Q}=\mathrm{Q}, \\
& \mathrm{A}^{*}=\mathrm{C}, \\
& \ln \mathrm{K}=\mathrm{k}, \\
& \ln \mathrm{L}=\mathrm{L}, \\
& \ln \mathrm{T} / \mathrm{L}=\mathrm{RA}
\end{aligned}
$$

\section{Estimation of results for all seaport with technological proxy}

Dependent Variable: Q

Method: Least Squares

Date: 01/27/06 Time: 10:52

Sample(adjusted): 19812005

Included observations: 25 after adjusting endpoints

Convergence achieved after 6 iterations 


\begin{tabular}{|c|c|c|c|c|}
\hline Variable & Coefficient & Std. Error & t-Statistic & Prob. \\
\hline $\mathrm{C}$ & -1.221246 & 0.448871 & -2.720704 & 0.0132 \\
\hline $\mathrm{K}$ & 0.635830 & 0.102831 & 6.183270 & 0.0000 \\
\hline $\mathrm{T} / \mathrm{L}$ & 0.320493 & 0.137391 & 2.332703 & 0.0302 \\
\hline $\mathrm{R}$ & 0.272534 & 0.085015 & 3.205699 & 0.0044 \\
\hline $\operatorname{AR}(1)$ & 0.106261 & 0.084635 & 1.255520 & 0.2238 \\
\hline R-squared & 0.994063 & \multicolumn{2}{|c|}{ Mean dependent var } & 8.492891 \\
\hline Adjusted R-squared & 0.992875 & \multicolumn{2}{|c|}{ S.D. dependent var } & 1.034683 \\
\hline S.E. of regression & 0.087335 & \multicolumn{2}{|c|}{ Akaike info criterion } & -1.861275 \\
\hline Sum squared resid & 0.152548 & \multicolumn{2}{|c|}{ Schwarz criterion } & -1.617500 \\
\hline Log likelihood & 28.26594 & \multicolumn{2}{|l|}{ F-statistic } & 837.1502 \\
\hline Durbin-Watson stat & 1.731050 & \multicolumn{2}{|c|}{ Prob(F-statistic) } & 0.000000 \\
\hline Inverted AR Roots & \multicolumn{3}{|l|}{.11} & \\
\hline $\begin{array}{l}\ln Q=-1.2212 \\
\mathrm{Se}=(0.4488) \\
\mathrm{t}=(-2.721)\end{array}$ & $\begin{aligned}+\quad & 0.63583 \ln \mathrm{k} \\
& (0.1028) \\
& (6.1832)\end{aligned}$ & \multicolumn{2}{|c|}{$\begin{array}{c}+0.32049 \ln \mathrm{L} \\
(0.1374) \\
(2.3327)\end{array}$} & $\begin{array}{l}534(\mathrm{~T} / \mathrm{L}) \\
85) \\
57)\end{array}$ \\
\hline
\end{tabular}

$\mathrm{n}=1980-2005(26), \quad \mathrm{R}^{2}=0.994, \quad$ Adj $\mathrm{R}^{2}=0.992, \quad$ DW 1.731, $\quad \mathrm{F}=837.1502$

\section{Test the statistical significance}

\section{Using t test.}

Let us postulate that,

$$
\begin{aligned}
& \mathrm{H}_{0}: \mathrm{A}^{*}=0, \mathrm{a}=0, \mathrm{~b}=0, \mathrm{Z}=0 \\
& \mathrm{Hi}: \mathrm{A}^{*} \# 0, \mathrm{a} \# 0, \mathrm{~b} \# 0, \mathrm{Z} \# 0
\end{aligned}
$$

For example the null hypothesis $\left(\mathrm{H}_{0}\right)$ states that, holding, $\mathrm{A} * \mathrm{~b} \mathrm{z}$ Constant, capital input $(\mathrm{k})$ has no (linear) influence on output (gross port revenue) To test the null hypothesis, we use the " $\mathrm{t}$ " test.

$$
\begin{array}{ccccc}
\hat{t}= & \hat{\mathrm{A}^{*}} & \hat{\mathrm{a}} & \hat{\mathrm{b}} & \hat{\imath} \\
& \frac{\hat{\mathrm{se}}(\mathrm{A})}{\operatorname{se}(\mathrm{b})} & \frac{\mathrm{z}}{\operatorname{se}(\mathrm{z})}
\end{array}
$$

According to our study calculated t values are $\mathbf{- 2 . 7 2 1 , 6 . 1 8 3 2 , ~ 2 . 3 3 2 7 , ~ 3 . 2 0 5 7 ~ f o r ~}$ intercept $\mathrm{a}, \mathrm{b}$ and $\mathrm{z}$ respectively.

Our critical $t$ value is

\section{For 5\% level $\quad \mathbf{2 . 0 8 0}$}

In these calculations, partial coefficients including the intercept are significant at the 0.05 per cent level for the two-tail test, standard errors are very small. 


\section{Goodness of fit $\left(\mathbf{R}^{2}\right)$}

\section{$\mathbf{R}^{2}=\mathbf{0 . 9 9 4}$}

More than 99 per cent of the variation in seaport output is explained by the variation in explanatory variables.

\section{Using F test}

$\mathrm{H}_{0}: \mathrm{A}^{*}=\mathrm{a}=\mathrm{b}=\mathrm{Z}=0$

Hi : $A^{*} \# \mathrm{a} \# \mathrm{~b} \# \mathrm{Z} \# 0$

Here calculated $F$ value is $\mathbf{8 3 7 . 1 5 0 2}$

Critical $\mathrm{F}$ value from $\mathrm{F}$ table,

$\mathrm{F}_{0.05(3,21)}=\mathbf{3 . 0 5}$

Because $837.1502>4.71$ we can reject Ho . That is the hypothesis that $\mathrm{A}^{*}, \mathrm{a}, \mathrm{b}, \mathrm{z}$ are jointly different from zero. That is the F statistics is significant at the 0.05 per cent level

\section{DW statistics}

DW statistics is significant at 0.05 per cent level which indicates the absence of first order serial correlation

\section{An Economic Interpretation}

The partial slope coefficient of 0.63583 indicates the partial elasticity of the output with respect to capital. Specifically, this means that, if labor input are held constant and capital input increase by 1 per cent on average output will increase by 0.64 per cent. Likewise, if capital inputs are held constant, and if labor input increases by 1 per cent on average output increases by 0.32 per cent. If we add together the two output elasticity coefficients of factor input, we obtain an economically important parameter called the returns to scale parameter. Which gives the response of output to proportional change in inputs? The sum of two elasticity coefficient of capital and labor is 0.95632 , suggesting that the Sri Lanka major seaports (Colombo Galle and Trincomalee) exhibit decreasing returns to scale doubling the input gives less than double the output. However, this tentative conclusion has been influenced by the technological proxy ${ }^{4}$, which explicitly assumed that all seaports have the same traffic structure and the same capital/labor ratios over time. Therefore this proxy has been dropped, in order to bring to the fore the direct relationship between inputs and outputs in major seaports in Sri Lanka. Dropping the proxy for technological developments gives the following results.

\section{Estimation of results for all seaport without technological proxy}

Dependent Variable: Q

Method: Least Squares

Date: 01/27/06 Time: 11:41

Sample(adjusted): 19822005 
Included observations: 24 after adjusting endpoints Convergence achieved after 7 iterations

\begin{tabular}{|c|c|c|c|c|}
\hline Variable & Coefficient & Std. Error & t-Statistic & Prob. \\
\hline $\mathrm{C}$ & -1.609457 & 0.598987 & -2.686966 & 0.0146 \\
\hline $\mathrm{K}$ & 0.508069 & 0.143834 & 3.532334 & 0.0022 \\
\hline $\mathrm{L}$ & 0.673986 & 0.125689 & 5.362350 & 0.0000 \\
\hline $\operatorname{AR}(1)$ & 0.335557 & 0.221218 & 1.516860 & 0.1458 \\
\hline $\operatorname{AR}(2)$ & -0.093246 & 0.110143 & -0.846585 & 0.4078 \\
\hline R-squared & 0.990240 & \multicolumn{2}{|c|}{ Mean dependent var } & 8.562052 \\
\hline Adjusted R-squared & 0.988185 & \multicolumn{2}{|c|}{ S.D. dependent var } & 0.996161 \\
\hline S.E. of regression & 0.108278 & \multicolumn{2}{|c|}{ Akaike info criterion } & -1.425181 \\
\hline Sum squared resid & 0.222758 & \multicolumn{2}{|c|}{ Schwarz criterion } & -1.179753 \\
\hline Log likelihood & 22.10217 & \multicolumn{2}{|l|}{ F-statistic } & 481.9344 \\
\hline Durbin-Watson stat & 2.095700 & \multicolumn{2}{|c|}{ Prob(F-statistic) } & 0.000000 \\
\hline Inverted AR Roots & $.17+.26 \mathrm{i}$ & \multicolumn{2}{|l|}{$.17-.26 \mathrm{i}$} & \\
\hline $\ln \mathrm{Q}$ & -1.6095 & $0.5081 \ln \mathrm{k}$ & $0.6740 \ln \mathrm{L}$ & \\
\hline $\mathrm{Se}$ & $(2.6870)$ & $(3.5323)$ & $(5.3624)$ & \\
\hline$=$ & $(0.5990)$ & $(0.1438)$ & $(0.1257)$ & \\
\hline $\mathrm{R}^{2}=0.990$ & $\mathrm{R}^{2}=0.988$ & $\mathrm{DW}=2.0957$, & $F=481.9344$ & \\
\hline
\end{tabular}

Statistically this result may be interpreted as follows. All partial coefficients, intercept, capital and labor are significant at the 0.05 per cent level. Standard errors are very small, the F statistics is significance at the 0.05 per cent level, and the variation of 99 per cent in seaport output is explained by the variation in explanatory variables. The DW statistics is significance at 0.05 per cent, which indicates the absence of first order serial correlation.

\section{An Economic Interpretation}

Economic interpretation of these results is as follows: The partial slope coefficient of 0.5081 indicates the partial elasticity of the output with respect to the capital input (k). This number indicates that, if the labor input is held constant, and capital input increases by 1 percent on average, seaport output will increase by 0.50 per cent. Likewise, if capital input is held constant, while labor inputs increases by 1 per cent on average, output will increase by 0.67 per cent. This interpretation contains an important policy message. That is labor and capital equally responsive to output of seaports in Sri Lanka. This is very much compatible with the factor endowments of the country. In order to further, substantiate an argument the possibilities of substituting labor for capital can be ascertained using the constant elasticity substitution (CES) production function or trans-log production function, which do not assume the unitary elasticity of substitution as does the Cobb-Douglas production function. However, this aspect is beyond the 
limits of our analysis. Especially these aspects are suitable for the study, which deals with factor substitution and technical progress of seaports. The sum of the capital and labor elasticity coefficient is 1.182055 , suggesting that Sri Lanka major seaport showed increasing returns to scale during the 1980-2005 period. According to the results of these regressions, the productivity growth in the seaport was quite rapid. This rapid growth indicates that the demand for the seaport services has been increasing during the past two decades. Furthermore its indicates that there are more possibilities to expand seaport facilities and thereby reduce the seaport congestion, which has automatically been created by excess demand. However this rapid growth pertained mainly to the Colombo seaport rather than Galle or Trincomalee. To analyze the situation in Colombo Seaport these two functions only estimated for Colombo seaport.

\section{Estimation of models for the Colombo Seaport}

The first model makes estimates for the Colombo seaport using the OLS method. The results are as follows:

\section{Estimation of results for Colombo seaport with technology proxy}

Dependent Variable: Q

Method: Least Squares

Date: 01/28/06 Time: 10:36

Sample(adjusted): 19812005

Included observations: 25 after adjusting endpoints

Convergence achieved after 6 iterations

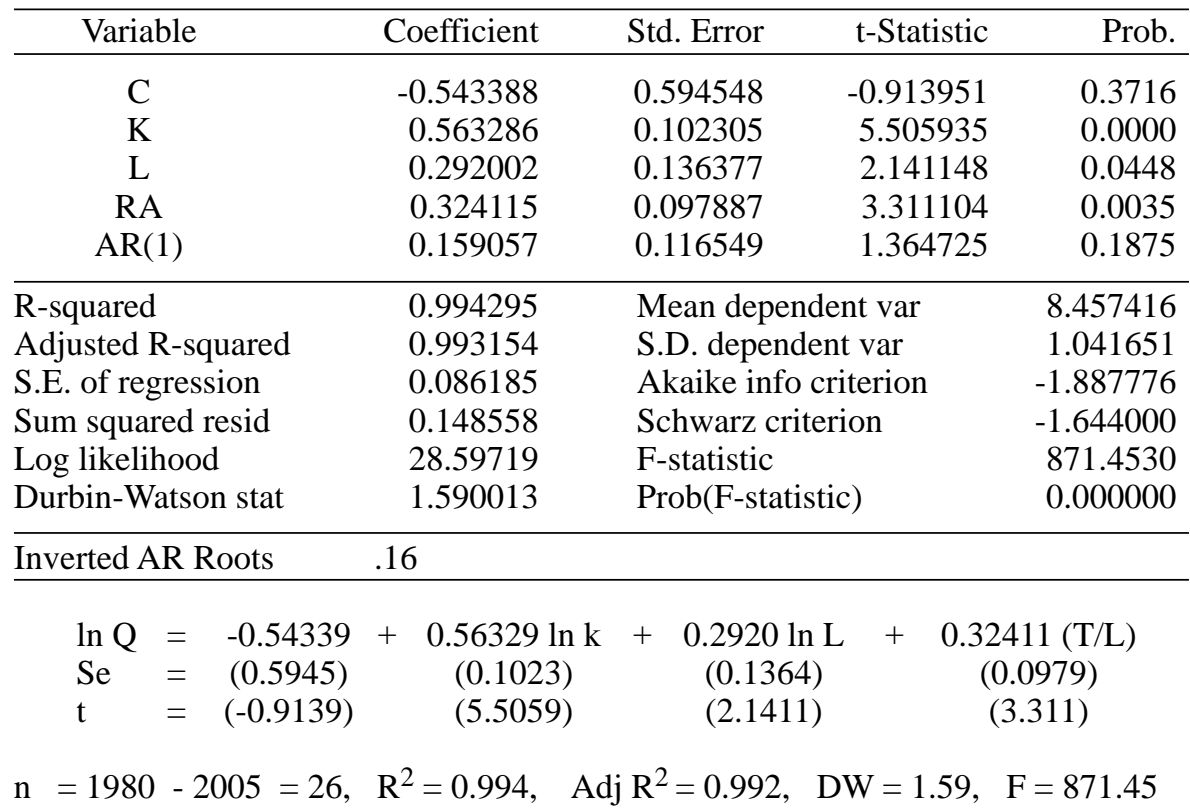


Statistically these results may be interpreted as follows: The partial coefficients excluding intercept are significant at 0.05 per cent, but intercept is at 0.1 percent significance. Standard errors are very small, more than 99 per cent of the variation in seaport output is explained by the variation in explanatory variables, the F statistics is significant at the 0.05 per cent level and the DW statistic is significant at 0.05 per cent level, which indicates the absence of positive first order serial correlation.

\section{An Economic Interpretation}

Economically these results may be interpreted as follows: if labor input are held constant, and if capital input increase by 1 per cent on average output will increase by 0.56 per cent. If capital input is held constant, and if labor input increase by 1 per cent on average, output increases by 0.29 per cent. The sum this capital and labor elasticity coefficient is 0.86 which suggests that the Colombo seaport has had decreasing returns to scale during the 1980-2005 period. However, the government invested heavily in the Colombo seaport, to cope with the increasing traffic, and this caused the rapid changes in the capital output ratios. Therefore, the second model drops the technological proxy, in order to ascertain the direct relationships between input and output in the Colombo seaport.

\section{Estimation of results for Colombo seaport without technology proxy}

Dependent Variable: Q

Method: Least Squares

Date: 01/28/06 Time: 11:04

Sample(adjusted): 19822005

Included observations: 24 after adjusting endpoints

Convergence achieved after 6 iterations

\begin{tabular}{|c|c|c|c|c|}
\hline Variable & Coefficient & Std. Error & $\mathrm{t}$-Statistic & Prob. \\
\hline $\mathrm{C}$ & -1.574528 & 0.653040 & $-2.41 \quad 1075$ & 0.0262 \\
\hline $\mathrm{K}$ & 0.523844 & 0.149568 & 3.502370 & 0.0024 \\
\hline $\mathrm{L}$ & 0.652038 & 0.128905 & 5.058286 & 0.0001 \\
\hline $\operatorname{AR}(1)$ & 0.389901 & 0.218799 & 1.782002 & 0.0907 \\
\hline $\operatorname{AR}(2)$ & -0.098740 & 0.114279 & -0.864025 & 0.3984 \\
\hline R-squared & 0.990323 & \multicolumn{2}{|c|}{ Mean dependent var } & 8.527170 \\
\hline Adjusted R-squared & 0.988286 & \multicolumn{2}{|c|}{ S.D. dependent var } & 1.002639 \\
\hline S.E. of regression & 0.108517 & \multicolumn{2}{|c|}{ Akaike info criterion } & -1.420763 \\
\hline Sum squared resid & 0.223744 & \multicolumn{2}{|c|}{ Schwarz criterion } & -1.175335 \\
\hline Log likelihood & 22.04916 & \multicolumn{2}{|l|}{ F-statistic } & 486.1117 \\
\hline Durbin-Watson stat & 2.095957 & \multicolumn{2}{|c|}{ Prob(F-statistic) } & 0.000000 \\
\hline Inverted AR Roots & $.19+.25 \mathrm{i}$ & \multicolumn{2}{|l|}{$.19-.25 \mathrm{i}$} & \\
\hline
\end{tabular}




$$
\begin{aligned}
& \ln \mathrm{Q}=-1.5745+0.5238 \ln \mathrm{k}+0.6520 \ln \mathrm{L} \\
& \mathrm{t} \quad=(-2.4111) \quad(3.5024) \\
& \mathrm{Se} \quad=(0.6530) \quad(0.1496) \quad(0.1289) \\
& \mathrm{R}^{2}=0.990, \quad \text { Adj } \mathrm{R}^{2}=0.988, \quad \mathrm{DW}=2.0957, \quad \mathrm{~F}=481.9344
\end{aligned}
$$

Statistically these results may be interpreted as follows: Capital and labor partial coefficient is significant at the 0.05 per cent level. However, the intercept has 0.62 per cent probability of significance. Standard errors are very small and the F statistic is significant at the 0.05 per cent level. More than 88 per cent of the variation in output is explained by the variation in explanatory variables. The DW statistic is significant at the 0.05 per cent level, indicating the absence of first order serial correlation.

\section{An Economic Interpretation}

Economically these results may be interpreted as follows: If the labor input is held constant, and capital input increases by one per cent on average, output increases by 0.64 per cent Likewise, if capital input is held constant, and labor input increase by one per cent on average, output increases by 0.41 per cent. The sum of labor and capital coefficient is 1.5 , which suggests that Colombo seaport has shown increasing returns to scale in the recent past: doubling inputs more than double the output. Colombo seaport uses the inputs optimally, or operates more or less in the minimum area of the long -run cost curve which may be the minimum efficient scale. That is why any South Asian seaport can not compete with Colombo and it is the most competitive seaport in South Asian region.

\section{PRODUCTIVITY BASED PROFITABILITY ANALYSIS IN THE COLOMBO SEAPORT}

The following max-min model is used to show the sustainable nature of profitable operation in the Colombo seaport based on the productivity analysis during 19802005 period.

$$
\begin{aligned}
& \text { Maximize: } \mathrm{Q}=\mathrm{wL}+\mathrm{rK} \\
& \text { Subject to: } \mathrm{Q}=\mathrm{AK}^{\mathrm{a}} \mathrm{L}^{\mathrm{b}}
\end{aligned}
$$

Where, $\mathrm{Q}=$ Gross revenue from port activities (1980 price), $\mathrm{w}=$ Average annual total earning per employee (1980 prices), $\mathrm{K}=$ Net assets (book values, 1980 prices), $\mathrm{L}=$ Number of employees, $\mathrm{a}$ and $\mathrm{b}=$ Capital and labour coefficients, $\mathrm{r} \%=$ Rate of return on capital; (Q-wL)/K.

Solving this model by using the Lagrange multiplier:

$$
\begin{aligned}
& \mathrm{w}=\mathrm{y} 1(\mathrm{~b} \cdot \mathrm{Q} / \mathrm{L})=\mathrm{y} 1 \mathrm{MPPl} \text { in Rupee value } \\
& \mathrm{r}=\mathrm{y} 2(\mathrm{a} \cdot \mathrm{Q} / \mathrm{K})=\mathrm{y} 2 \mathrm{MPPk} \text { in per cent terms }
\end{aligned}
$$

Where y1 and y2 = Lagrange multipliers for labour and capital, MPPl = Marginal Physical Productivity of Labour (AP1*b), MPPk = Marginal Physical Productivity of Capital $\left(\mathrm{APk}^{*} \mathrm{a}\right), \mathrm{APl}=$ Average Productivity of Labour $(\mathrm{Q} / \mathrm{L}), \mathrm{APk}=$ Average Productivity of Capital (Q/K), MRPl = Marginal Revenue Product of Labour $(\mathrm{MP} 1 * \mathrm{w})$, $\mathrm{MRPk}=$ Marginal Revenue Product of Capital $\left(\mathrm{MPk}^{*} \mathrm{r} \%\right)$. 
Capital coefficient, $\mathrm{a}=0.575347$ and Labor coefficient, $\mathrm{b}=0.574628$ obtained through estimating function through $\mathrm{E}$ views which is presented in annexure table 1 .

All calculation for this model is shown the following table 1.

Table 1. Profitability analysis for the Colombo seaport 1980-2005

\begin{tabular}{|c|c|c|c|c|c|c|}
\hline Year & Wage rate & MRPI = & Y1 = & $\mathrm{r} \%$ & MPPk = & $Y 2=$ \\
\hline & $(w / L)=w$ & $(\mathbf{M P I} * \mathbf{w})$ & (w/MRPI) & $(\mathbf{Q}-\mathbf{w L}) / \mathrm{k}$ & $\left(\mathbf{M P k}^{*} \mathbf{r} \%\right)$ & (r/MPPk) \\
\hline 1980 & 16433 & 131,027 & 0.12541 & 2.4197 & 3.3686 & 0.71830 \\
\hline 1981 & 16271 & 253,350 & 0.06422 & 2.8164 & 4.5639 & 0.61711 \\
\hline 1982 & 16604 & 105,600 & 0.15724 & 2.4382 & 3.4203 & 0.71286 \\
\hline 1983 & 16610 & 117,939 & 0.14084 & 8.3722 & 40.3293 & 0.20760 \\
\hline 1984 & 16465 & 198,350 & 0.08301 & 9.5892 & 52.9058 & 0.18125 \\
\hline 1985 & 16762 & 105,084 & 0.15951 & 6.2649 & 22.5822 & 0.27743 \\
\hline 1986 & 16388 & 132,425 & 0.12375 & 5.5856 & 17.9503 & 0.31117 \\
\hline 1987 & 16521 & 119,159 & 0.13864 & 3.9648 & 9.0442 & 0.43838 \\
\hline 1988 & 17355 & 265,321 & 0.06541 & 3.1853 & 5.8377 & 0.54565 \\
\hline 1989 & 18078 & 188,978 & 0.09566 & 2.4305 & 3.3988 & 0.71511 \\
\hline 1990 & 18818 & 366,642 & 0.05133 & 2.1026 & 2.5437 & 0.82661 \\
\hline 1991 & 19278 & 137,990 & 0.13970 & 1.8131 & 1.8914 & 0.95860 \\
\hline 1992 & 19645 & 105,270 & 0.18661 & 2.2766 & 2.9820 & 0.76345 \\
\hline 1993 & 20063 & 287,788 & 0.06971 & 7.5643 & 32.9206 & 0.22977 \\
\hline 1994 & 20680 & 95,382 & 0.21681 & 6.4340 & 23.8177 & 0.27014 \\
\hline 1995 & 21404 & 444,140 & 0.04819 & 6.0000 & 20.5554 & 0.29190 \\
\hline 1996 & 20391 & 327,824 & 0.06220 & 9.5692 & 29.8775 & 0.32028 \\
\hline 1997 & 18583 & 122,220 & 0.15204 & 4.2148 & 10.2130 & 0.41270 \\
\hline 1998 & 18062 & 205,010 & 0.08810 & 2.5260 & 3.6711 & 0.68808 \\
\hline 1999 & 18616 & 143,841 & 0.12942 & 2.1775 & 2.7279 & 0.79821 \\
\hline 2000 & 18257 & 53,688 & 0.34006 & 3.9054 & 8.7753 & 0.44504 \\
\hline 2001 & 18984 & 168,015 & 0.11299 & 9.8209 & 44.3433 & 0.22147 \\
\hline 2002 & 19674 & 152,965 & 0.12862 & 1.1855 & 0.8087 & 1.46606 \\
\hline 2003 & 26432 & 623,191 & 0.04241 & 3.2169 & 5.9539 & 0.54030 \\
\hline 2004 & 26739 & 155,762 & 0.17167 & 4.8342 & 13.4457 & 0.35954 \\
\hline 2005 & 26019 & 172,619 & 0.15073 & 3.1287 & 5.6319 & 0.55553 \\
\hline Mean & 19197 & 199,215 & 0.12478 & 4.5322 & 14.3677 & 0.53356 \\
\hline S.D & 3041 & 126,267 & 0.0637 & 2.6421 & 14.7839 & 0.2939 \\
\hline
\end{tabular}

Source: Calculation is based on the unpublished data obtained from the Financial Division of the Sri Lanka Ports Authority. 
Assuming that labor and capital coefficients remained constant during the sample period (1980-2005), the marginal productivities of labor and capital can be obtained by multiplying input coefficients with their respective average productivities. The Lagrange multiplier (y1.y2) measures the deviation of returns to input factors from their marginal productivities, which has been derived by dividing returns to input factors by their marginal productivities. An economically important two main profitability measures are well above the acceptable level. That is, the average marginal revenue product of seaport labor is well above the average wage rate paid for seaport labor [w(19197) < MRPI (199215)] and the average marginal revenue product of capital is well above the average interest rate paid for the port development loans $[\mathrm{r} \%(4.53)<\mathrm{MRPk} \%=(14.37)]$. The average interest rate on the government bonds during 1980 - 2004 period was 14.62 per cent well below the MRPk percentage (CBSL: 2004). However, the majority of port development loans was granted by concessionary development cooperation sources and thus did not have real commercial origins. Wages in Colombo seaport are mainly determined by the labor market and by trade unions exogenous to the labor productivity in the seaport, speed-up money collection is widespread among port labors, and this may be an indirect compensation for the low wages. Therefore, capital always yields a high profitability for investment without raising wages. The average Lagrange multiplier for labor (y1) equals 0.12478 for capital (y2) it equals 0.53356 . This indicates the relative stability of returns to input factors from the marginal productivities over time. In accounting terms however the major share of the gross port profit in the Colombo seaport is paid to the Government as tax revenue and subsidize the losses in other major seaports, which are administered and manage by the Sri Lanka Ports Authority. Therefore, the Colombo seaport does not retain sufficient surplus to reinvest for future development. This may be the main reason that Colombo seaport continues to depend heavily on development co-operation sources. However, if the private sector can be encourage participating in different areas in seaport operations, this dependency could be lessened.'

\section{CAPACITY UTILIZATION ANALYSIS IN THE COLOMBO SEAPORT}

Capacity utilization is the ideal measure to show the proportion of seaport productive capacity currently utilized from the available maximum port capacity ${ }^{5}$. This is a good indicator to determine the potential future expansion of seaport facilities without creating over capacity. Often, the excess demand for seaport services leads to an expansion of seaport facilities without prior proper assessment of the utilization of the available capacity. Particularly, in developing countries without proper assessment of the utilization of the existing capacities, development of new capacities are widespread practice due to many factors. These practices might waste scarce resources, which aggravate the existing economic problems by giving priorities for unnecessary expensive infrastructure. Before the expansion of the existing seaport facilities begins, it is preferable to carry out a capacity utilization analysis. The calculation of the ratios of capacity utilization in the Colombo seaport is based on the actual tonnage handled and the preferred tonnage. We assume that the preferred tonnage indicates the preferred level of capacity utilization (capacity output). Thus, the ratios of actual to preferred tonnage in the port of Colombo are derived in the following sequences. First, the port capacity function is specified as follows: 


\section{$\mathbf{T}=\mathbf{f}($ Time, $\mathbf{H})$}

Where,

$$
\mathrm{T}=\text { actual tonnage handle, } \quad \mathrm{H}=\text { dummy variable for peak tonnage. }
$$

After the trend line of the actual tonnage handled has been identified, the following function is specified.

Where,

$$
\mathbf{T}=\mathbf{a}+\mathbf{b} \text { time }+\mathbf{c}(\text { time })^{2}+\mathbf{d ~ H} \text { time }^{2}
$$

$$
\mathrm{TIME}^{2}=\mathrm{T} 2
$$

Has been introduced after the quadric behavior of actual tonnage over time has been identified. First, this function is calculated using the OLS method, and later first order auto-correlation is removed using the first order auto-regression [ar (1)].

\section{Estimation of results of capacity utilization for Colombo seaport.}

Dependent Variable: T

Method: Least Squares

Date: 01/28/06 Time: 12:18

Sample(adjusted): 19822005

Included observations: 24 after adjusting endpoints

Convergence achieved after 10 iterations

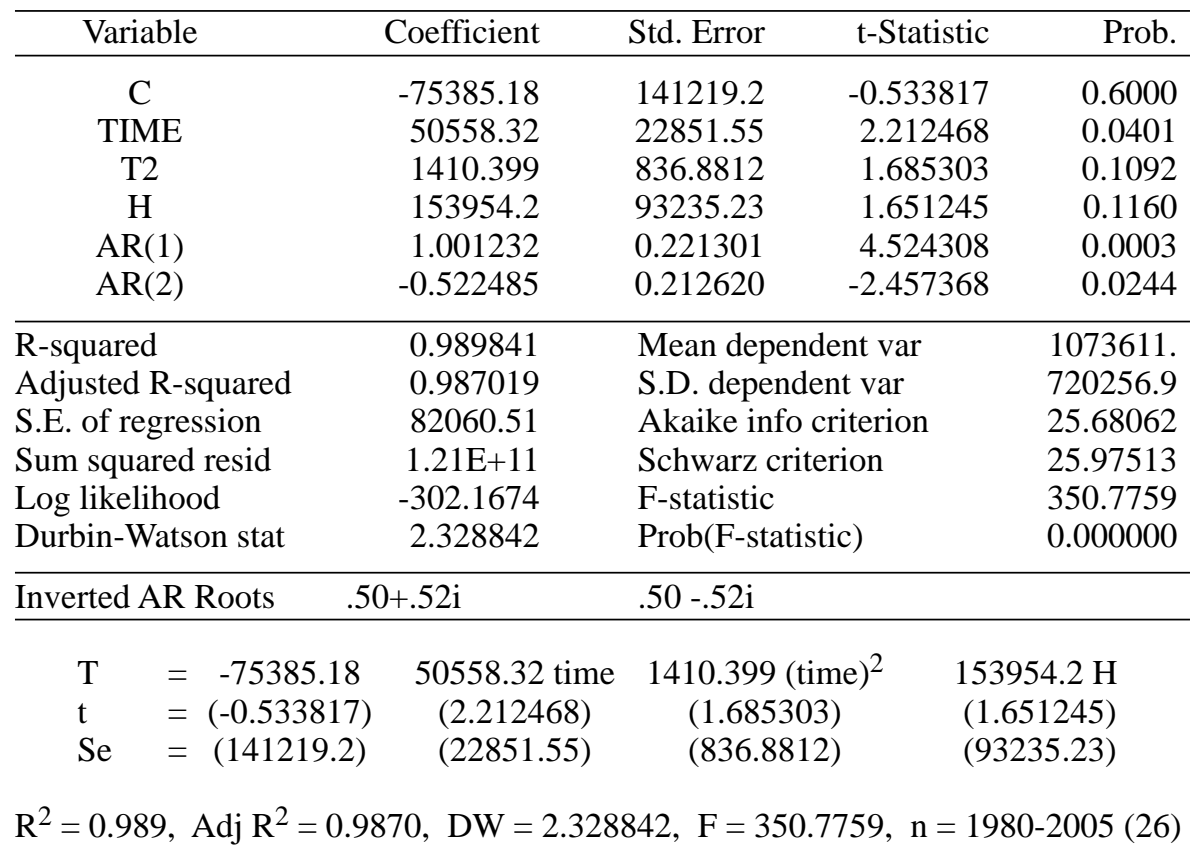


In these calculations, partial coefficient of time variable is significant at the 0.05 per cent level, but other variables excluding intercept are significant at 10 per cent level for the two tail test, 98 per cent of the variation in preferred tonnage is explained by the variation in the explanatory variables, the $\mathrm{F}$ statistic is significant at 0.05 per cent and the DW statistic is significant at 0.05 per cent level, which indicates the absence of first order auto-correlation. This equation shows that annual rate of increase of tonnage in the port of Colombo has been positive, and that the rate has increased over time at an increasing rate:

$$
\begin{aligned}
& \mathrm{dt} / \mathrm{d}(\text { time })=50558.32+2820.798 \text { time, and } \\
& \mathrm{d}^{2} \mathrm{~T} / \mathrm{d}^{2}(\text { time })=2820.798 .
\end{aligned}
$$

Based on the above regression equation, the preferred tonnage (PT) function can be specified as:

$\mathrm{PTi}=-75385.18+50558.32$ time $+1410.399(\text { time })^{2}+153954.2 \mathrm{H}$

Where,

$$
\mathrm{i}=\text { from } 1980 \text { to } 2005 \text { and } \mathrm{H}=1 \text {. }
$$

Following this definition, preferred tonnage for the 1980-2005 period is computed using the PTi equation by plugging the time variable and $\mathrm{H}=1$ for every period into equation. This shows in the following table.

Table 2. The derived ratios of actual to preferred tonnage in Colombo seaport, 1980-2005

\begin{tabular}{|c|c|c|c|}
\hline Year & $\begin{array}{c}\text { Actual } \\
\text { Tonnage(T) }\end{array}$ & $\begin{array}{c}\text { Preferred } \\
\text { Tonnage(PT) }\end{array}$ & $\begin{array}{c}\text { Capacity } \\
\text { Utilization(T/PT)\% }\end{array}$ \\
\hline 1980 & 41625 & -23416 & neglect \\
1981 & 59471 & 31373 & 190 \\
1982 & 106120 & 88983 & 119 \\
1983 & 146590 & 149414 & 98 \\
1984 & 187727 & 212666 & 88 \\
1985 & 220207 & 278739 & 79 \\
1986 & 348142 & 347633 & 100 \\
1987 & 435618 & 419347 & 104 \\
1988 & 628485 & 493882 & 127 \\
1989 & 551810 & 571238 & 97 \\
1990 & 595356 & 651415 & 91 \\
1991 & 669488 & 734412 & 91 \\
1992 & 675776 & 820230 & 94 \\
1993 & 858398 & 908870 & 97 \\
1994 & 972642 & 1000329 & 96 \\
1995 & 1049044 & 1094610 & 114 \\
1996 & 1356301 & 1191712 & \\
\hline
\end{tabular}




\begin{tabular}{|c|c|c|c|}
\hline Year & $\begin{array}{c}\text { Actual } \\
\text { Tonnage(T) }\end{array}$ & $\begin{array}{c}\text { Preferred } \\
\text { Tonnage(PT) }\end{array}$ & $\begin{array}{c}\text { Capacity } \\
\text { Utilization(T/PT)\% }\end{array}$ \\
\hline 1997 & 1687184 & 1445588 & 117 \\
1998 & 1714077 & 1548331 & 111 \\
1999 & 1704389 & 1653895 & 103 \\
2000 & 1732855 & 1762280 & 98 \\
2001 & 1726605 & 1873485 & 92 \\
2002 & 1764694 & 1987511 & 89 \\
2003 & 1959336 & 2104359 & 93 \\
2004 & 2220525 & 2224026 & 100 \\
2005 & 2455293 & 2346515 & $\mathbf{9 2}$ \\
Average & $\mathbf{9 9 4 9 1 4}$ & $\mathbf{9 9 6 8 2 4}$ & Statictical \\
\hline
\end{tabular}

Source: Calculation is based on the published data obtained from the Statistical Division of the Sri Lanka Ports Authority.

This table 2 shows that the average rate of capacity utilization was around 92 per cent in the Colombo seaport during 1980-2005. In some years, the capacity utilization was over 100 per cent, which indicates heavy congestion, long waiting queues for ships and avoidance of Colombo by ships, etc. Further, not all the ship calling at the port could be served efficiently, and the by pass rate is very high for the main lines. The main limitation of this capacity utilization analysis is that some peak tonnage marked off, as full capacity utilization peaks when in fact, there may have been considerable under utilization of seaport capacity. According to the latest estimation made by the Sri Lanka Ports Authority in 2006 Oct., the Colombo's container handing (3.3 million TEU) capacity will be saturated in year 2008. Therefore this may be the right time to speed-up the work of Colombo South harbor to accommodate emerging mega ships between two growth engines of the world: China and India. The present harbour basin within the port will not be able to accommodate vessels with a length of 400 metres. Approximately 30 percent of the ships coming on stream are 8000 TEU plus vessels having a draft of 15 to 16 metres which the present port cannot cater to. In the $1980 \mathrm{~s}$ the average size of a ship was 975 TEUs with the largest being 3,057 TEUs. Today the average size of a ship is 2191 TEUs while the largest in the world fleet is 9200 TEUs. There are designs in place for the construction of Malacca Max with a capacity of 18100 TEUs and Samzung Suez Max with a capacity of 14000 TEUs. If the Colombo seaport does not develop inline with world maritime development, mega container vessels then have no other option except to opt for modern ports such as Salala-Aiden, Port of Dubai, Tanjum Pelapase of Malaysia or the Port of Singapore. The close Indian ports such Chennai is also developing fast and it would become a hub in the region in the near future, if Colombo do not act promptly to utilize its supreme hub location.

\section{CONCLUSIONS AND POLICY REMARKS}

The main contents of this analysis may be finalized in the following form of conclusions. 
The analysis based on the Cobb-Douglas production function has shown that the operation of the Colombo seaport increasing return to scale during the recent past. The returns to scale depend to a larger extent upon changing demand for seaport services and corresponding development to cope with this demand. In view of the rapidly rising tonnage handled in many types of cargo such as container, bulk, breakbulk and liquid and the other maritime services provided for ships and the related other business activities by the Colombo seaport after the 1977 policy reforms has reasonable evidences to find increasing returns to scale in our estimated models even with some what ambiguous data set.

The analysis of the section 2 is elaborated the profitable operation of the Colombo seaport based on the productivity analysis. The average profitability measures such as $\mathrm{W}<\mathrm{MRPI}$ and $\mathrm{r} \%<\mathrm{MRPk} \%$ are well above the acceptable limits. The sustainable nature of profitable operation are well above the acceptable limits. This sustainable nature of profitable operation well elaborates with little fluctuation of Lagrange multipliers over time.

The capacity utilization analysis shows the annual rate of increase of tonnage at the Colombo seaport has been positive and, the rate has increased at an increasing rate over time and finally, it shows the high rate of actual to preferred capacity utilization which can be used as a basis to expand seaport facilities without creating the problem of overcapacity. This expansion can be within Colombo seaport itself or any other new port in Sri Lanka.

\section{Notes}

${ }^{1}$ This economic policy reforms mainly included: Liberalization of most of imports and exchange payments. Abolition of most price controls while keeping a system of administered prices for certain products of importance in the society's consumption pattern and grant of greater autonomy to public corporations for more realistic pricing policies in order to help them to achieve commercial viability. Attempts to reduce budgetary expenditure on account of food subsidies by introducing a system of 'food stamps' whereby stamps of a given value were issued to low income families and market forces were allowed generally to determine the prices of commodities purchasable with these stamps (safety net with market forces). Promotion of private enterprises, including direct foreign investment through a wide array of fiscal, infrastructural and other incentives. Restraint in granting wage demands in general and those within the public sector in particular along with repressive measures on the trade union movements. An appearance of restrictiveness in monetary measures marked by unprecedented high interest rates and intermittent credit squeezes imposed on commercial bank lending. Apart from short periods of these credit squeezes, however, private and public sectors do not seem to have encountered much difficulty in obtaining the required bank credit. In that respect, easy money conditions have been maintained. Sharp increases in government capital expenditure, particularly on infrastructure and housing project, despite the fact that this necessitated the running of large budget deficits, even if they had to be bridged through inflationary finance. Search for increasing volumes of 
foreign aids, loans and grants. Sharp (Mono) devaluation of currency. Measures to promote economic activities earning foreign exchange (export-oriented industry, export crops, tourism, labour migration for foreign jobs etc.). Hence the claim of the proponents of the 'open economy that their strategy is one of 'export-led growth'.

${ }^{2}$ The major changes introduced under the liberalization of shipping are: from Central Freight Bureau (CFB) regulations to liberalization, from a pivot of cargo monopsony to ship owner competition, fro national line priority to foreign line precedence, from CFB negotiated rates to free market prices, from a lean sailing regime to prolific service oriented regime, from dominance of the CFB to the resurrection of the Ceylon Association of Steamer Agents (CASA) and shipping Council, from a Central Freight Booking Office to primacy of Colombo hub port, and promotion of private foreign and local investment to different areas in the maritime industry. From 1990 on wards this maritime sector liberalization continued by all the successive political regimes.

${ }^{3}$ The theoretical defects and abuse of studies of port impact and cost/benefits are very much controversial issue in seaport literature. For details see Waters (1977); Chang (1978ab), and Peter and Rose (1995). Port impact and cost/benefits studies are different from the studies of port performance and efficiency. Seaport performance and efficiency are mainly related with stevedores (equipments and labour related), shipping lines (turn around time) and port itself (facility utilization and throughput). The most important determinants of the seaport performance and efficiency are explained by Tongzon (1995). However, the most acceptable single seaport performance indicators is shadow price based port throughput per profit unit.

${ }^{4}$ Generally, technological change measures by introducing time variable to general production function. Our first model is using per-capita tonnage as proxy for the technological changes which in-line with the assumption of the labour-augmenting Harrod's neutral technological progress because capital-output ratio of Sri Lanka's seaports showed a relatively stable picture during 1980-93 periods. In our model, Harrod and Hicks neutral assumptions on technological progress are equivalent because elasticity of substitution is unitary even returns to scale is not unitary. It is generally believed that the Cobb-Douglas production function is embodied with the technological progress therefore a separate proxy is not necessary. For given values of $\mathrm{K}$ and $\mathrm{L}$, the magnitude of A (intercept) will proportionately affect the level of Q. Hence A may be considered as an efficiency parameter, i.e., as an indicator of the state of technology. Therefore, included technological proxy has dropped from our model because of this reality.

${ }^{5}$ Capacity output and capacity utilization are very difficult to measure in seaports. The most popular capacity utilization measures are Wharton school index based on Klien and Preston method (1996) and Tally method (1998, 1994). The Wharton school index is constructed by making off cyclical peaks of production and then computing ratios of actual to the linear trend line fitted through these peaks. This method assumes that cyclical peaks represent the full capacity utilization. Tally method measures full capacity utilization in engineering point of view. Two types of engineering optimum 
outputs were introduced. First, the theoretical optimum engineering output which is the maximum (designed) throughput of a port when it is operating at its maximum rate of efficiency. Second, the optimum empirical engineering output which is the estimated maximum throughput based upon actual port data. However, most of the seaport capacity utilization studies were used 'actual' and 'preferred' capacity utilization rather than 'full' capacity utilization.

\section{REFERENCES}

Chang, S. (1978a). Production function, productivities and capacity utilization of the port of Mobile', Maritime Policy and Management, 5, 297-305.

Chang, S. (1978b). In defense of port impact studies', Transportation Journal, Spring 1978, $79-85$.

Central Bank of Sri Lanka (CBSL) (2005). Annual Report, Sri Lanka.

Containerization International Year Book: 2003, National Magazine Company, UK.

Dharmasena, K. (1980). The port of Colombo: 1860-1939, Published Ph.D. thesis submitted to University of London, 1970.

Douglas, W., Laurits, R., and Joseph, A. (1981). Productivity growth, scale of economics and capacity utilization in U.S. rail roads -1955-74, American Economic Review, Vol. 71, pp. 994-I002.

ECAFE (1966/67). The ports of Ceylon Report by the port team of the United Nation Economic Commission for Asia and Far East, Nov. 1960 and March 1967, mimeo.

Klein, R., and Preston, R. (1967). The measurement of capacity utilization, American Economic Review, March, 34-58.

Markarov, L., Levin, J., and Rubinov, M. (1995). Mathematical Economic Theory, Pure and Mixed Types of Economic Mechanisms, Advanced text books in economics, 33, Elsevier publication.

Peter, G., and Rose, G. (1995). The impact of a port on its local economy: the case of Plymouth, Maritime Policy and Management, Vol. 22, No. 1, pp. 13-23.

Sri Lanka Ports Authority (SLPA) (1979/2005). Port statistics Series, Statistical Division, Colombo seaport.

Sri Lanka Ports Authority (SLPA) (1980/2005). Annual Accounts, Financial Division, unpublished series. 
Tally, W. (1988). Optimum throughput and performance evaluation of marine terminals, Maritime Policy and Management, Vol. I5, No. 4, 327-331.

Tally, W. (1994). Performance indicators and port performance evaluation, Transportation Review, Vol. 30, No. 4, 339-351.

Tongzon, L. (1995). Determinants of port performance and efficiency, Transportation Research, Vol. 29A, No. 3, 245-252.

UNCTAD (1995). The establishment of Transhipment Facilities in Developing Countries, TD/B/C.4/AC.7/10.

UNCTAD (1994). Review of Maritime Transport -1993.

Waters, C. (1977). Port economic impact studies: Practice and assessment, Transportation Journal, Spring 1977, 14-18.

Yes, leadership is about vision. But leadership is equally about creating a climate where the truth is heard and the brutal facts confronted. There's a huge difference between the opportunity to "have your say" and the opportunity to be heard. The good-to-great leaders understood this distinction, creating a culture wherein people had a tremendous opportunity to be heard, and ultimately, for the truth to be heard. Jim Collins 